\title{
CULTURAL AND CREATIVE INDUSTRIES IN URBAN TOURISM INNOVATION - THE EXAMPLE OF THE CITY OF RIJEKA
}

\author{
Christian Stipanović \\ Elena Rudan \\ Vedran Zubović
}

https://doi.org/10.20867/tosee.05.47

\begin{abstract}
Purpose - The aim of the research is to determine the role of cultural and creative industries in the creation of innovative urban tourism with particular focus on the city of Rijeka as European Capital of Culture 2020. The research is directed towards the new trends in urban cultural tourism and the possibilities of innovating tourism offer in the process of repositioning. The purpose of this paper is to determine the current level of tourism development of the city of Rijeka and the future development.

Methodology - The paper analyses the theoretical determinants of the synergy between cultural and creative industries and tourism in innovating urban tourism offer. It analyses the present state of cultural and creative industries and tourism of the city of Rijeka and, through in-depth interviews of representatives of cultural and creative industries and tourism offer, as well as through benchmarking analysis, it determines the possibilities for innovating the city's cultural offer in line with the vision of the city as a recognizable cultural tourism destination.

Findings - The results can be observed on two levels; the theoretical level, exploring the role of cultural and creative industries in innovating urban cultural tourism offer, and the applicative level that explores the current situation, development scenario and the synergy of tourism and cultural creative industries on the example of Rijeka as the European Capital of Culture 2020. The role of cultural and creative industries in building and innovating cultural tourism offer represents the basis for developing Rijeka as an urban cultural destination.

Contribution - The paper defines the cultural and creative industries value chain and its potentials in urban value chain innovation, especially in urban destinations titled the European Capitals of Culture. The research should be extended to other destination stakeholders (e.g. local population, student population, etc.) to further concretize the possibilities for synergy in enhancing the operational strategies for transforming Rijeka into a recognizable urban destination.
\end{abstract}

Keywords cultural and creative industries, tourism, cities, innovation, city of Rijeka

\section{INTRODUCTION}

In modern economies, cultural and creative industries are initiators of change in urban centres seeking to develop a specific image and distinctiveness, with regard to the people living in those centres as well as with regard to visitors sojourning there. The cities and towns of Croatia, and the businesses operating within them, have in recent years experienced steady development aimed at making them centres distinctive for innovations in tourism. Such distinctiveness is based on the results of cultural and creative industries, particularly in the development of diverse sub-forms of cultural tourism. A variety of information sources are available to modern tourists, sources that 
ToSEE - Tourism in Southern and Eastern Europe, Vol. 5, pp. 655-666, 2019

C. Stipanović, E. Rudan, V. Zubović: CULTURAL AND CREATIVE INDUSTRIES IN URBAN ...

open the destination to the market and ensure the visibility of a city's cultural and creative offering. Leisure, education, the Internet, digital technology, diverse information sources and traffic accessibility have enabled cities to intensify their development and continuously make innovations to their tourism industry. Cities are often recognised for the events they host and, particularly in Europe, they develop into must-see year-round destinations. The distinctiveness of cities in the tourism market opens up new opportunities for their economic development, hence the importance and role of cultural and creative industries in the tourism of cities.

\section{LITERATURE OVERVIEW}

In recent years, researchers have increasingly begun to focus on cultural and creative industries in the broadest context, exploring their intersectoral connections, with sectors such as tourism and education, across all levels, ranging from local and regional to international. Although different authors define the cultural and creative industries in different ways, most definitions are based on the terms creativity and innovativeness. According to Peris-Ortiz, Gomez and Lopez-Sieben $(2019,3)$ cultural and creative industries signify the intrinsic manifestation of humanity's capacity to think, create, innovate and design that generates economic value. These industries, whose origin lies in talent, skill and creativity and are now enriched by technology, include architecture and design, fashion design and advertising (Goldstein, 2016, 22). According to Gandar $(2017,16)$, organisations that make up the cultural and creative industries involve the production of products or services that are mainly made up of symbolic benefits. That which is valued in a dance, a song or in designer clothes has a defined initial value (intellectual property) which is not based on the standards and measurements used in other industries.

The development of cultural and creative industries is encouraged by European Union policies that recognise the importance of these industries to the modern economy and support their growth (European Commission, Culture). Goldstein $(2016,52)$ observes that certain EU countries began to develop creative industries in the late 1990s and early 2000s based on widely differing programmes and starting from different levels. The Baltic countries, for example, have mapped their creative industries and have accurately pinpointed resources. Other countries, such as Austria, have opened colleges and faculties to promote and manage creative industries. Some regions have established departments for the development of creative industries. Worldwide, cultural and creative industries are also seeing continuous growth and, according to the 2015 report by Ernst $\&$ Young, they generated US\$ 2,250 billion in revenue (3\% of the world's GDP) and employed about 29.5 million people. Because cultural and creative industries provide employment to $1 \%$ of the world's active work force, there is a constant need to study the contributions of these industries to the individual economies as well as their synergistic action with other sectors. In the European economy, cultural and creative industries are recognised as job generators with a significant share in the economy. Researchers underscore that cultural and creative industries are tremendous contributors to the creation of jobs, companies, and quality of life across all markets. Boccella and Salerno (2016) state that today, cultural and creative industries are driving factors for economic growth and, in accordance with global demand, are also stimulated by the new economy. 
ToSEE - Tourism in Southern and Eastern Europe, Vol. 5, pp. 655-666, 2019

C. Stipanović, E. Rudan, V. Zubović: CULTURAL AND CREATIVE INDUSTRIES IN URBAN

Goldstein $(2016,134)$ confirms this, pointing out that cultural and creative industries generate a positive effect that surpasses the mere economic development of a region and often contributes towards developing, or even creating, an identity, thus impacting a city/town or region. At play is a combination of creation and consumption at the local level, which helps to improve quality of life while making the tourist destination more attractive.

Because they are integrated into every element of a modern offering, well-developed cultural and creative industries are a prerequisite to the development of different specialinterest forms of tourism. Especially important in this respect is the development of cultural tourism and all its sub-forms, one of which is creative tourism (Stipanović, Rudan, 2014), anchored in the creativity, management and entrepreneurship of cultural and creative industries, of tourism and hospitality, and of all stakeholders involved in the supply chain. According to Della Lucia, Trunfio and Go (2017, 182), developing successful creative tourism forms involves collaboration with a wide, dispersed value network rather than with a narrow value chain: different creative content and lifestyles need to be combined in the tourism experience, both in the city and at a distance, or even virtually, via new technology. There is an opportunity for everyone to participate in a creative process which is the result of creative work based on an authorial idea (Tomašević, 2015, 50-51). The creative classes and creative processes are focused on collaborating on creative ideas. Skavronska $(2017,93)$ underlines the role of a creative environment which is the basis for the implementation and development of innovative and creative thinking but which, at the same time, itself is undergoing transformation under the impact of creative thinking, reflecting dynamic changes in socio-economic, institutional and organizational areas. Author Florida (2002, 250, 223) emphasizes that the success of the cities in creative economy is based on a strong "creative class" based on "3T" technology, tolerance and talent. Furthermore, the author says that regional economic growth is driven by their location choices of creative people - the holders of creative capital - who prefer places that are diverse, tolerant and open to new ideas. Landry (2008) underlines that cities have one crucial resource - their people. Human cleverness, desires, motivations, imagination and creativity are replacing location, natural resources and market access as urban resources. The creativity of those who live in and run cities will determine future success.

Cultural and creative industries are particularly important in cities that encourage the creation of cultural identity that is focused not only on residents but on non-residents tourists - as well. Cities are spaces that provide new opportunities to develop creativity (Richards, 2014). Clearly, such development has been facilitated by a variety of programmes, such as the European Capital of Cultural programme, which has been running since 1983. The programme has helped to drive the development of cultural tourism and, as Liu $(2014,510)$ suggests, it has ensured resources for the growth of tourism, urban and economic regeneration, and the materialisation of a plurality of cultures. An example of this is the Slovenian town of Maribor, the 2012 European Capital of Culture, where the programme provided a link between the tourism and hospitality sector of Maribor and other Slovenian towns and culture promoters. A communication platform was created that could be used for the continued marketing of cultural tourism in Slovenia. The project European Capital of Culture 2012 identified culture as a product that could be exploited in destination marketing (Kovač, Srakar, 2013). According to 
ToSEE - Tourism in Southern and Eastern Europe, Vol. 5, pp. 655-666, 2019

C. Stipanović, E. Rudan, V. Zubović: CULTURAL AND CREATIVE INDUSTRIES IN URBAN ...

the data of the Statistical Office of the Republic of Slovenia, in 2012, when Maribor was a European Capital of Culture, the number of tourist arrivals to the town increased by $23 \%$ and the number of overnights, by $20 \%$, relative to 2011 .

Contrary to Maribor, the example of Košica (Slovakia) shows no increase in the numbers of tourist arrivals or overnights in 2013 when the Slovakian city was a European Capital of Culture. Šebova et al. (2014) reported that, according to indicators, the most notable visitors were Slovakian tourists $(88 \%)$ and local residents. There was a great effort made to set tourism on a new development route, based not only on traditional cultural tourism such as museums and galleries but also on new modern experimental forms of culture (street art, festivals).

\section{SYNERGISTIC ACTION - THE ROAD TO INNOVATIVE TOURISM IN URBAN DESTINATIONS}

The road to innovative tourism lies in the synergistic action of all stakeholders in a tourist destination. Cultural and creative industries are key stakeholders in the modern understanding of innovation in all special-interest forms of tourism, particularly in forms developed in city spaces. Urban destinations are, indeed, areas where such synergistic action is demonstrated to the fullest extent. Della Lucia and Segre (2017) argue that the synergistic action of value chains in the cultural and creative industries and tourism of cities can result in faster and better regional economic development.

Dragićević-Šešić and Stojković $(2013,67)$ find it interesting that many cities, whose financial and economic power is declining, have begun to invest more in culture and are engaged in the cultural restoration of what was created in the time of earlier financial prosperity. Such cities have put in place well-designed cultural polices and even small towns that see their future in tourism are seeking to create a positive image. These efforts are evident in the numerous summer festivals held throughout Europe, the sculpture parks in open-air urban spaces, art colonies, art fairs, various workshops (painting, photography, etc.) and street events. Examples of such cities are Glasgow, Essen, Nantes and others. Cities are putting investment in culture and creativity at the centre of their local development strategies to support policy objectives, ranging from urban regeneration and economic diversification and rejuvenation to job creation and social innovation and cohesion. (The Cultural and Creative Cities Monitor). In the Cultural and Creative Cities Monitor, the European Commission presents 168 cities in 30 countries, described through 29 indicators relating to nine areas that reflect three major aspects of the cities' cultural, creative and economic vigour. These are Cultural Vibrancy, measuring the cultural "pulse" of a city with regard to cultural infrastructure and involvement in culture; Creative Economy, indicating how the cultural and creative sector contributes towards employment, job creation and innovation capacity; and Enabling Environment, highlighting the tangible and intangible assets of cities that help to attract creative talent and encourage involvement in culture. 
ToSEE - Tourism in Southern and Eastern Europe, Vol. 5, pp. 655-666, 2019

C. Stipanović, E. Rudan, V. Zubović: CULTURAL AND CREATIVE INDUSTRIES IN URBAN

The European Capital of Culture programme and creative city programmes have provided additional impetus to such ideas of strong cultural and creative cities in Europe. According to Ho $(2017,64)$, the "art" and "culture" activities with the least profit-seeking feature begin to play a central role in adding value to urban land and in attracting capital and talent. Madudova $(2017,228)$ also explores supply chain innovation and points out that cultural and creative enterprises bring innovations to other sectors due to their marked tendency to cooperate with others.

Jelinčić and Žuvela $(2013,82)$, following Haselbach, define three development models of cities based on cultural and creative industries. The first model is "City with a New Face", which focuses on changing the positioning of a city, using financial schemes other than those the city itself can support; hence the important role of national and regional authorities in this model. The second model is "Cultural and Creative City", where the policies of cultural and creative industries are culture-oriented. Cultural and creative industries are at the centre of the culture policies which are implemented by city and regional authorities. In addition to providing support to entrepreneurs, policies also focus on support to individual initiatives in a broader sense (festivals, creative initiatives, developing a creative atmosphere, educational studies). The third model is the "Entrepreneurial Cultural and Creative City", in which a cultural and creative industry policy approach is concentrated within the sector itself and the development policy is enforced by the city authorities. The city should ensure the appropriate business environment. Slavuj (2011) states that understanding that place and community attachment influence people's behaviour can help in using these connections for local development processes and positive community achievements. The synergistic action of all stakeholders in cultural and creative industries and all tourism and hospitality offering providers, travel agencies and residents is essential to ensure the innovation of an urban destination's tourism product.

The creation of new forms of urban cultural tourism assumes that the culture policies of cities are in place and/or resource bases are available that will enable the inclusion of cultural and creative industries in regional development and in the creation of the cities' urban identities.

Stakeholder action in the value chain is established with emphasis on each link in the chain (culture policy, cultural and creative industry, residents, and the tourism and hospitality sectors) and its ability to perform as an integrated part of the city system and in its development. Stipanović, Rudan and Zadel (2018) stress that strategic cultural tourism development management based on the synergy of cultural and creative entrepreneurship and the tourism sector, the culture of collaboration, horizontal and vertical linkage and active inclusion of all stakeholders represent the basis for considerations of urban cultural tourism development in the process of achieving selfsustainability and multiplication of profits. 
ToSEE - Tourism in Southern and Eastern Europe, Vol. 5, pp. 655-666, 2019

C. Stipanović, E. Rudan, V. Zubović: CULTURAL AND CREATIVE INDUSTRIES IN URBAN ...

\section{ANALYSIS OF THE CURRENT STATE OF INTERACTION BETWEEN TOURISM AND THE CULTURAL AND CREATIVE INDUSTRIES OF RIJEKA}

In recent years, the Town of Rijeka has increasingly begun to capitalise on its untapped tourism-related potential. The reasons for this change and greater shift towards tourism clearly lie in the fact that the town's industries are basically fading and the Port of Rijeka is no longer as active as its competitors, Koper in Slovenia and Trieste in Italy. To counter the decline in production industries and the failure to proactively encourage the development of the productive sectors and transportation lines, Rijeka is seeking to develop as an urban tourism destination and city of culture. Rijeka has been chosen as the 2020 European Capital of Culture, further reinforcing the town's efforts to become a distinctive urban tourism destination.

Recent years have seen a steady growth in tourism performance in Rijeka. According to the Rijeka Tourist Board (2019), the total number of beds in Rijeka was 6,739. The town has four hotels with 555 beds, two boarding houses with 396 beds, 15 hostels with 419 beds, student and pupils' halls with 1,472 beds (operating during school holidays) and private accommodation with 963 accommodation units and 3,897 beds. In 2018, Rijeka saw 155,396 tourist arrivals, $16 \%$ more than in the same period in 2017, and recorded 407,902 overnights, a $22 \%$ increase relative to 2017 .

In Croatia, no special statistics are kept regarding cultural and creative industries. Instead, they are monitored within the framework of other areas. In addition to the individual basic cultural and creative industries of Rijeka, it is important to underline education, the creative potential of young, educated people focused on culture and art as well as on industries related to culture and art. Despite being insufficiently developed, the cultural and creative industries of Rijeka possess the foundation for development (cultural resources; the creativity of human potential; education focused on culture and art at all levels; museums - Museum of the Town of Rijeka, Museum of Modern and Contemporary Art, the Rijeka Natural History Museum, Maritime and History Museum of the Croatian Littoral, the Peek\&Poke Museum of Childhood; galleries and exhibitions; music; theatres - Croatian National Theatre Ivan Zajc, Rijeka Puppet Theatre, Croatian Cultural Centre at Sušak, HKD Theatre; designers: publishers; well-known cultural and other events - Rijeka Carnival, Rijeka Summer Nights, International Small Scene Theatre Festival, Summer at the Hill-fort, etc.). The Rijeka Cultural Development Strategy by 2020 underlines intellectual and creative potential as one of the town's key economic resources and provides measures to facilitate the networking of entrepreneurs, creative artists and the academic community, to ensure spatial conditions for creativity and to encourage entrepreneurial projects that combine artistic creativity and technological innovation. According to the Cultural and Creative Cities Monitor, Rijeka has a C3 Index of 20.2 and Creative Economy Index of 14.4. This is lower than the indexes of, for example, Zagreb (C3 Index of 25.9, and Creative Economy Index of 28.3) or Ljubljana (C3 Index of 32.7, and Creative Economy Index of 33.3). Rijeka's indexes suggest that the town needs to make additional efforts to ensure more space for, and further boost the development of, cultural and creative industries. Such development will also ensure an outlet for people to realise their creative potential. 
ToSEE - Tourism in Southern and Eastern Europe, Vol. 5, pp. 655-666, 2019

C. Stipanović, E. Rudan, V. Zubović: CULTURAL AND CREATIVE INDUSTRIES IN URBAN ...

\section{RESEARCHING STAKEHOLDERS IN CULTURAL AND CREATIVE INDUSTRIES REGARDING OPPORTUNITIES TO IMPROVE THE TOURISM INDUSTRY OF RIJEKA}

To study the role of stakeholders in cultural and creative industries, in-depth interviews were conducted with 17 respondents. Five of the respondents are employed in the cultural and creative industries sector, three are workers in organising cultural and art activities, three are members of associations engaged in cultural programmes, three are independent artists and three are workers in tourism and hospitality. The structure sample of respondents is limited by the importance of stakeholders who are decision makers related on creation, management and development of cultural and creative industries in tourism. The deep interview included various types of questions (open questions, evaluation, ranking) in order to detect how key stakeholders percept the current situation and future development (certain difficulties have been recognized due to fact that some stakeholders were not able to take a second round of interview). Efforts were made to encompass stakeholders involved in the system of creating, managing and developing cultural and creative industries, with a focus on tourism. Up to date, half of the respondents are engaged in some of the European Capital of Culture 2020 programmes. The study was conducted during January and February 2019. In the quantitative part of the study, the respondents rated the tourism and cultural offering of Rijeka with an average score of 2.8 (on a Likert scale, ranging from 1 to 5). The level of participation of cultural and creative industries in the tourism offering received a low score (average score of 2.0). The respondents rated the importance of participation in destination distinctiveness and branding with an average score of 4.7. Promotional and marketing activities focused on the cultural tourism offering had an average score of 2.2. When asked to identify the most competitive and most important cultural and tourism events in Rijeka, the respondents stated the Rijeka Carnival, followed by Rijeka Summer Nights; in their opinion, all other events are indistinctive. The respondents were also asked to rate the involvement of various stakeholders in designing the cultural and creative tourism offering. The participation of associations received the highest score (3.6), followed by creative and cultural industry providers (3.4) and residents (3.2).

Table 1: Involvement of stakeholders in designing the cultural and creative tourism offering of Rijeka

\begin{tabular}{|l|c|c|}
\hline Stakeholders & Average & Std. deviation \\
\hline Rijeka Tourist Board & 2.8 & 1.3 \\
\hline Local government and self-government & 2.2 & 0.84 \\
\hline Supply providers (tourism, hospitality) & 3 & 0.71 \\
\hline Residents & 3.2 & 0.45 \\
\hline County Tourist Board & 2.6 & 1.34 \\
\hline Small entrepreneurs in hospitality and tourism & 3 & 0.71 \\
\hline Associations & 3.6 & 0.55 \\
\hline Creative and cultural industry providers & 3.4 & 0.55 \\
\hline Overall score of stakeholder collaboration & $\mathbf{2 . 6}$ & $\mathbf{1 . 1 4}$ \\
\hline
\end{tabular}

Source: Authors' research 
ToSEE - Tourism in Southern and Eastern Europe, Vol. 5, pp. 655-666, 2019

C. Stipanović, E. Rudan, V. Zubović: CULTURAL AND CREATIVE INDUSTRIES IN URBAN ...

When asked to identify and analyse competitor cities, the respondents reported Zagreb, Ljubljana, Trieste, Pula, Opatija and Poreč. Zagreb, which has in recent years made qualitative and quantitative advancements in creating its cultural tourism product, was the city most often mentioned in response to this question.

Following the survey, qualitative text analysis was conducted to identify the categories in which cultural and creative industry stakeholders described the opportunities and issues related to cultural and creative industry involvement. NVivo 12 software was used for the qualitative processing of data. Most of the text could be summarized in the following categories and dimensions (Table 2.).

Table 2: Qualitative categories and dimensions

\begin{tabular}{|c|c|c|}
\hline & Category & Dimension \\
\hline 01 & Competitors & $\begin{array}{ll}\text { - } & \text { Zagreb, Pula, Opatija, Poreč } \\
\text { - } & \text { Ljubljana } \\
\text { - } & \text { Trieste } \\
\end{array}$ \\
\hline 02 & $\begin{array}{l}\text { Problems in designing the } \\
\text { offering }\end{array}$ & $\begin{array}{l}\text { Poor involvement and low interest on the part } \\
\text { of stakeholders } \\
\text { - } \quad \text { Lack of systems' support for the development } \\
\text { of a cultural and creative offering } \\
\text { - } \quad \text { Limited funding } \\
\text { - Conflicts of interest among business entities, } \\
\text { and communication issues } \\
\text { - Low level of creativity and innovativeness on } \\
\text { the part of creators of the offering } \\
\text { Failure to identify new trends in cultural and } \\
\text { creative tourism } \\
\text { Adverse political, economic, legal and } \\
\text { administrative influences } \\
\text { Lack of interest on the part of tourists for such } \\
\text { an offering }\end{array}$ \\
\hline 03 & Improving promotion & 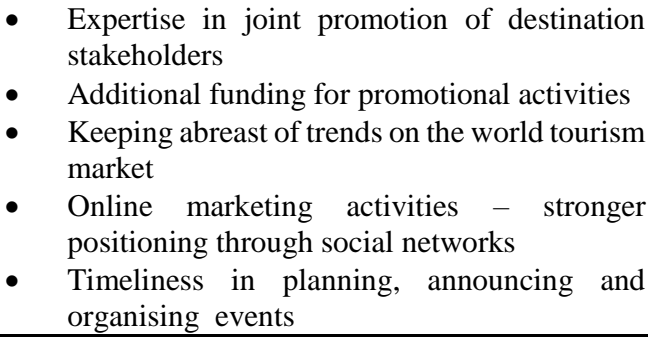 \\
\hline 04 & $\begin{array}{l}\text { Managing tourism } \\
\text { development }\end{array}$ & 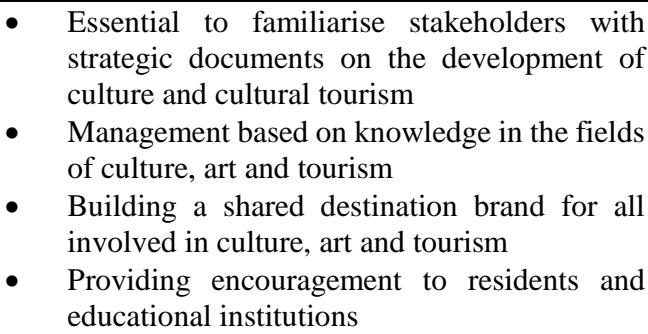 \\
\hline
\end{tabular}


ToSEE - Tourism in Southern and Eastern Europe, Vol. 5, pp. 655-666, 2019

C. Stipanović, E. Rudan, V. Zubović: CULTURAL AND CREATIVE INDUSTRIES IN URBAN ...

\begin{tabular}{|l|l|ll|}
\hline & \multicolumn{2}{|c|}{ Category } & \multicolumn{1}{c|}{ Dimension } \\
\hline & & $\bullet \quad \begin{array}{l}\text { ECoC programme poorly recognised by } \\
\text { stakeholders who could become involved in its } \\
\text { realisation in the future }\end{array}$ \\
05 & $\begin{array}{l}\text { ECoC in strengthening the } \\
\text { involved stakeholders }\end{array}$ & $\begin{array}{l}\text { Improving the flow of information between } \\
\text { stakeholders and organisers } \\
\text { Visibility in the environment, especially with } \\
\text { regard to residents }\end{array}$ \\
\hline
\end{tabular}

Source: Authors' research

Qualitative research has established the great importance of cultural and creative industries in designing the cultural tourism product of an urban destination. Respondents gave an average score of 4.7 to the importance of the cultural and creative offering in enhancing the distinctiveness and branding of Rijeka as an urban tourism destination. Research also confirms that with regard to the importance of the promotion of individual business entities, priority is given to integrated promotion that should be set up by the tourist board or other organisations vital to city promotion and branding. Rijeka needs to make innovations to its tourism industry based on the resource bases that it possesses (cultural resources, organisations in culture, events, etc. Weaknesses should be overcome through joint competition in the market, well-designed and timely promotional activities, and the action of all stakeholders who are in any way involved in innovating Rijeka's tourism industry. Key actors and entities engaged in developing and delivering the European Capital of Culture project also need to become a part of this collaboration.

Starting points for further tourism development include the visibility and transparency of the programme, synergistic action and the involvement of professionals from all domains of culture and art. To make the tourism offering more competitive, it will be necessary to keep abreast of modern trends in the presentation of cultural assets of cities (for example, in Zagreb and Vienna) with regard to cultural and creative industries. To further improve the offering will require the professional, integrated promotion of all destination stakeholders in modern communication with the market by continuously stimulating sales and promotional activities of cultural programmes for the purpose of creating an integrated tourism and cultural product. An effective response to market demands has to be based on value chain creation in the cultural and creative industries, in synergy with other stakeholders (tourism, hospitality, education, science, etc.) in the Rijeka urban area, because the town's people can only be as creative as the extent to which the space and opportunities provided by the town of Rijeka allows them to express their creativity.

\section{CONCLUSION}

Cultural and creative industries contribute towards innovativeness in developing city tourism in all the special interest sub-forms that a city wants to develop. Cultural and creative industries are present in every segment of urban space, seen from the perspective of residents as well as from the perspective of tourist stays and visits to city attractions. In the tourism market, the distinctiveness of cities is reflected in their ability to open up their spaces to the needs of modern tourists, while city inhabitants see it as a city's ability 
ToSEE - Tourism in Southern and Eastern Europe, Vol. 5, pp. 655-666, 2019

C. Stipanović, E. Rudan, V. Zubović: CULTURAL AND CREATIVE INDUSTRIES IN URBAN ...

to provide space that will ensure quality of life. The creativity of residents develops in spaces that can ensure its continuous growth. Such an "ideal" city is capable of ensuring the development of cultural and creative industries, thus contributing to the innovation of its tourism industry.

Support to such considerations is provided by cultural events, programmes and projects carried out over the years in the cities of Europe. One such programme is the European Capital of Culture, which reveals and provides new opportunities for urban spaces, foremost for residents but also for tourists.

The efforts of Rijeka to transform from an industrial town to a town of cultural, innovative tourism have been reinforced by its designation as the 2020 European Capital of Culture. To achieve its transformation, the town must encourage synergistic activities as well as joint efforts in promotional activities, ensure the visibility of programme solutions, and foster the presence and support of cultural policy in all dimensions of cultural and art development. Cultural and creative industries are one of the primary and key stakeholders in the process of transforming Rijeka from an industrial town to a town with a distinctive cultural identity in its environment. Building upon such future development would enable Rijeka to become a cultural city destination.

A limitation of this study is its small sample. Hence, future research could focus on the various sectors of cultural and creative industries (museums, libraries and heritage, art, music and the performing arts, design, film, photography, arts and crafts, architecture, computer programs, games and new media, electronic media, publishing and advertising, marketing communication).

\section{ACKNOWLEDGEMENTS}

This research has been financially supported by the University of Rijeka, for the project ZP UNIRI 1/17.

\section{REFERENCES}

Boccella, N., Salerno, I. (2016), "Creative economy, cultural industries and local development", Procedia social and behavioral sciences, Vol. 223, pp. 291-291, doi:10.1016/j.sbspro.2016.05.370.

Chih-Chung, H. (2017), "City branding and place -(un)making: The case study of the Taichung jazz festival", The International journal of organizational innovation, Vol. 9, No. 3, pp. 64-80.

Della Lucia, M, Trunfio, M., Go M. F. (2017), "Heritage and urban regeneration: towards creative tourism", in Bellini, N., Pasquinelli, C. (eds.), Tourism in the city: towards an integrative agenda on urban tourism, Springer, Gran Sasso.

Della Lucia, M. \& Segre, G., (2017), "Intersectoral local development in Italy: the cultural, creative and tourism industries”, International journal of culture, tourism and hospitality research, Vol. 11, No. 3, pp. 450-462. doi: 10.1108/IJCTHR-03-2016-0032.

Dragićević-Šešić, M., Stojković, B. (2013), Kultura: menadžment, animacija, marketing, Kulturno informativni centar,Zagreb.

Ernst \& Young (2015), Cultural times: the first global map of cultural and creative industries, December 2015.,viewed 15.1.2019,

https://en.unesco.org/creativity/sites/creativity/files/cultural_times._the_first_global_map_of_cult ural_and_creative_industries.pdf. 
ToSEE - Tourism in Southern and Eastern Europe, Vol. 5, pp. 655-666, 2019

C. Stipanović, E. Rudan, V. Zubović: CULTURAL AND CREATIVE INDUSTRIES IN URBAN ...

European Commision, the cultural and creative cities monitor a tool to promote mutual exchange and learning between cities to boost culture-led developmen, viewed 15 January 2019, https://composite-indicators.jrc.ec.europa.eu/cultural-creative-cities-monitor/.

European Commission, Culture: Supporting Europe's cultural and creative sectors, viewed 27 January 2019 , https://ec.europa.eu/culture/policy/cultural-creative-industries_en.

European Union (2017), The Cultural and creative cities monitor, viewed 15 January 2019, doi:10.2766/031627.

Florida, R. (2002), The rise of the creative class, Business books, New York.

Gander, J. (2017), Strategic analysis: a creative and cultural industries perspective, Routledge, London, New York.

Goldstein, S. (2016), Poduzetništvo u kreativnim industrijama, Hrvatska sveučilišna naklada, Zagreb.

Grad Rijeka (2013), Strategija kulturnog razvitka Grada Rijeke 2013-2020., viewed 28 January 2019, https://www.rijeka.hr/wp-content/uploads/2013/04/Strategija-kulturnog-razvitka-Grada-Rijeke2013.-\%E2\%80\%93-2020.pdf.

Grad Rijeka (2019), Grad Rijeka: Kultura, viewed 27 January 2019, https://www.rijeka.hr/teme-za-gradane/kultura-2/.

Ho, C. (2017), "City branding and place-(un) making: the case study of the taichung jazz festival", The international journal of organizational innovation, Vol. 9, No.3, pp. 64-81.

Institut za razvoj i međunarodne odnose (2015), Strategija razvoja kulturnog turizmu Rijeke: 2015. - 2020. viewed 10 January 2019, http://press.visitrijeka.hr/strateskiDokumenti/strategija_razvoja_ kulturnog_turizma_grada_Rijeka.pdf.

Jelinčić, D.A., Žuvela, A. (2013), “Što nas čini različitima? Kreativni Zagreb na putu prema kreativnoj Europi”, Medijske studije, Vol 4, No. 7, pp. 75-92.

Kovač, B., Srakar, A. (2013), Ekonomski učinki projekta Maribor 2012 - EPK, Univerza v Ljubljani, Ekonomska fakulteta, Ljubljana.

Landry, C. (2008), The creative city: A toolkit for urban innovators, $2^{\text {nd }}$ ed., London: Comedia, Earthscan.

Liu, Y. (2014), "Cultural events and cultural tourism development: lessons from the European capitals of culture", European planning studies, Vol. 22, No. 3, pp. 498-514.

Madudova, E. (2017), "Creative industries value chain: the value chain logic in supply chain relationships", Marketing and branding research, Vol. 4, No. 3, pp. 227-235, doi: 10.19237/MBR.2017.03.02

Peris-Ortiz, M., Gomez, J. A. and Lopez-Sieben, M. (2019), "Cultural and creative industries: an overview", in Peris-Ortiz, M., Rainiero Cabrera-Flores, M., Serrano-Santoyo, A. (Eds.), Cultural and creative industries: a path to entrepreneurship and innovation, Springer, Cham, pp. 1-13.

Richards, G. (2014), "Creativity and tourism in the city", Current issues in tourism, Vol. 17, No. 2, pp. 119144., doi:10.1080/13683500.2013.783794.

Rijeka 2020: Europska prijestolnica kulture, viewed 30 January 2019, https://rijeka2020.eu/en/

Skavronska, I.V. (2017), "Creative industries in Ukraine: analysis and prospects of the development", Economics and sociology, Vol. 10, No. 2, pp. 87-106, doi: 10.14254/2071-789X.2017/10-2/7.

Slavuj, L. (2011), "Urban Quality of Life - a Case Study: the City of Rijeka", Hrvatski geografski glasnik, Vol. 73, No. 1, pp. 99-110.

Statistični urad Republike Slovenije, (2018), viewed 30 January 2018 http://pxweb.stat.si/pxweb/Dialog/Saveshow.asp.

Stipanović, C., Rudan, E. (2014), "Development Concept and Strategy for Creative Tourism of the Kvarner Destination", Tourism \& Hospitality Industry 2014: Trends in Tourism and Hospitality Management , Perić, J. (ed.)., Fakultet za menadžment u turizmu i ugostiteljstvu, Opatija, 2014. pp. $1-8$.

Stipanović, C., Rudan, E., Zadel, Z. (2018), "Possibilities of entrepreneurial development in cultural tourism of croatian cities", Tourism \& Hospitality industry 2018: congress proceedings: 24th Biennial International Congress, Cerović, I., Smolčić Jurdana, D. (ed.), Faculty of Tourism and Hospitality Management Opatija, University of Rijeka, Opatija, pp. 431-442.

Šbova, M. et al. (2014), "Promoting and financing cultural tourism in Europe through European capitals of culture: a case study of Košice, European capital of culture 2013”, Economic Interferences, Vol. 16, No. 36, pp. 655-670.

Tomašević, N. (2015), Kreativna industrija i nakladništvo, Naklada Ljevak, Zagreb.

Turistička zajednica grada Rijeke (2019), Turistički promet na području grada Rijeke za razdoblje od 01.01.2018. do 31.12.2018. godine s usporedbom na isto razdoblje 2017. godine, TZ grada Rijeke, Rijeka. 
ToSEE - Tourism in Southern and Eastern Europe, Vol. 5, pp. 655-666, 2019

C. Stipanović, E. Rudan, V. Zubović: CULTURAL AND CREATIVE INDUSTRIES IN URBAN ...

Christian Stipanović, PhD, Full Professor

University of Rijeka

Faculty of Tourism and Hospitality Management

Primorska 42, 51410 Opatija, Croatia

Phone: +385-51-294-184

E-mail: christis@fthm.hr

Elena Rudan, $\mathrm{PhD}$, Assistant Professor

University of Rijeka

Faculty of Tourism and Hospitality Management

Primorska 42, 51410 Opatija, Croatia

Phone: +385-51-294-717

E-mail: elenar@fthm.hr

Vedran Zubović, MSc, Assistant

University of Rijekaž

Faculty of Tourism and Hospitality Management

Primorska 42, 51410 Opatija, Croatia

Phone: +385-51-294-194

E-mail: vedranz@fthm.hr 